\title{
Analisis Faktor-Faktor Yang Berhubungan Dengan Kejadian Anemia Pada Ibu Hamil Trimester III Di BPM Kusmawati Surabaya
}

\author{
Siska Nurul Abidah \\ Universitas Nahdlatul Ulama Surabaya, siskanurul@unusa.ac.id \\ Yasi Anggasari \\ Universitas Nahdlatul Ulama Surabaya, yasi@unusa.ac.id
}

\begin{abstract}
Abstrak
Kejadian anemia memberikan pengaruh buruk saat kehamilan. Prevalensi kejadian anemia tidak menunjukkan penurunan yaitu masih mencapai presentase $63,5 \%$. Penelitian ini bertujuan untuk menganalisis faktor-faktor yang berhubungan dengan kejadian anemia pada ibu hamil TM III. Penelitian ini menggunakan metode cross sectional study. Populasi dan sampel adalah ibu hamil TM III yang periksa di BPM Kusmawati Surabaya selama 3 bulan sebanyak 45 responden. Pengumpulan data berupa kuesioner dan buku register PWS KIA, menggunakan uji statistik Chi-Square. Hasil uji statistic, didapatkan tidak ada hubungan antara umur ibu dengan kejadian anemia $(\mathrm{p}=0,358)$, ada hubungan antara status gizi dengan kejadian anemia $(\mathrm{p}=0,000)$, tidak ada hubungan antara paritas dengan kejadian anemia $(\mathrm{p}=0,222)$, ada hubungan antara pemeriksaan kehamilan dengan kejadian anemia $(\mathrm{p}=0,000)$, ada hubungan antara pengetahuan dengan kejadian anemia $(\mathrm{p}=0,034)$, ada hubungan antara kepatuhan mengkonsumsi tablet $\mathrm{Fe}$ dengan kejadian anemia $(\mathrm{p}=0,024)$. Diharapkan petugas kesehatan agar terus meningkatkan penyuluhan dan konseling bagi ibu hamil untuk mencegah terjadinya anemia.
\end{abstract}

Kata kunci: Anemia, Ibu Hamil

\begin{abstract}
Anemia Events have a bad influence during pregnancy. The prevalence of anemia did not show a $63 \%$ decrease still reaching the percentage. This study discusses the factors associated with the incidence of anemia in pregnant women TM III. This study used a cross sectional study method.The population and samples were TM III pregnant women who examined themselves at BPM Kusmawati Surabaya for 3 months, 45 respondents. Data collection uses a questionnaire and PWS KIA register book, using Chi-Square statistical tests. The results of the statistical test showed that there was no relationship between mothers with anemia $(\mathrm{p}=0.358)$, there was a relationship between nutritional status and the incidence of anemia $(\mathrm{p}=0,000)$, there was no relationship between parity and anemia $(\mathrm{p}=0.222)$, there was a relationship between prenatal care with the incidence of anemia $(p=0,000)$, there was a relationship between knowledge and incidence of anemia $(p=0.034)$, there was a relationship between the administration of Fe tablets and the incidence of anemia $(\mathrm{p}=0.024)$. Health workers are expected to continue to improve counseling and counseling for pregnant women to get anemia permission.
\end{abstract}

Keywords: Anemia, Pregnant Women

\section{PENDAHULUAN}

Angka Kematian Ibu (AKI) merupakan

salah satu indikator ketidakberhasilan dalam memberi pelayanan kesehatan di suatu negara. Penderita anemia pada ibu hamil lebih banyak terjadi di negara berkembang 
dibandingkan dengan negara maju. Kematian ibu dapat terjadi karena beberapa sebab, diantaranya karena anemia (Amiruddin, 2007). Di Amerika hanya sekitar $6 \%$ ibu hamil yang menderita anemia, sedangkan di Indonesia relatif tinggi yaitu $63,5 \%$. Sebagian besar disebabkan karena kurangnya zat gizi dan perhatian terhadap ibu hamil sehingga dapat menyebabkan terjadinya anemia defisiensi zat besi (Saifuddin A.B, 2007).

Menurut WHO 4\% kematian ibu di negara yang sedang berkembang berkaitan dengan anemia, dalam kehamilan kebanyakan anemia disebabkan oleh defisiensi zat besi dan perdarahan akut, bahkan tidak jarang keduanya berinteraksi (Sarwono, 2009). Menurut WHO, kejadian anemia kehamilan berkisar antara 20\% sampai $89 \%$ dengan menetapkan $\mathrm{Hb} 11 \mathrm{~g} \%$ (g/dl) sebagai dasarnya. Angka kejadian anemia di Indonesia menunjukkan nilai yang cukup tinggi. Hoo Swie Tjiong menemukan angka anemia kehamilan sebear $3,8 \%$ pada trimester I, $13,6 \%$ pada trimester II dan $24,8 \%$ pada trimester III (Manuaba, 2012).

Di Indonesia anemia masih merupakan salah satu dari empat masalah gizi utama, disamping kurang kalori,protein, defisiensi vitamin A dan gondok endemik. Kematian ibu di negara berkembang berkaitan dengan anemia dalam kehamilan. Kebanyakan anemia dalam kehamilan disebab- kan oleh defisiensi zat besi dan pendarahan akut bahkan tidak jarang keduanya saling berinteraksi. (Sarwono, 2009)

WHO menyatakan kejadian anemia berkisar antara $20 \%$ sampai $89 \%$ dengan menetapkan HB normalnya 11 gr\%. Selain itu di daerah pedesaan banyak dijumpai ibu hamil kekurangan gizi, kehamilan dan persalinan dengan jarak yang berdekatan, dan ibu hamil dengan pendidikan dan tingkat sosial ekonomi rendah (Manuaba, 2012).

Penyebab kematian dibagi menjadi langsung dan tidak langsung. Kematian ibu langsung yaitu perdarahan $(24,72 \%)$, eklamsi (30,90\%), jantung (10,86\%), sepsis $(4,87 \%)$, dan penyebab lain sebesar $(28,65 \%)$. Sedangkan penyebab tidak langsung yang mendasar adalah faktor lingkungan, perilaku, genetik dan pelayanan kesehatan sendiri, salah satunya adalah $53 \%$ ibu hamil menderita anemia, 4 terlalu (hamil atau bersalin terlalu muda dan tua umurnya, terlalu banyak anak dan terlalu dekat jarak kehamilan / persalinannya). (Dinkes, 2016)

Berdasarkan studi pendahuluan pada bulan november 2018 dengan observasi dan wawancara dari 10 ibu hamil yang dilakukan wawancara 6 orang ibu belum mengetahui bahaya kehamilan dengan anemia dan berdasarkan hasil observasi rekam medis di BPM Kusmawati kejadian 
anemia pada ibu hamil masih cukup banyak.

Beberapa upaya telah dilakukan petugas Puskesmas dalam kegiatan promosi kesehatan untuk menurunkan angka kejadian anemia diantaranya dengan melakukan kegiatan yang meliputi penyuluhan dan konseling tentang pentingnya gizi bagi ibu hamil, pencegahan anemia, melakukan deteksi dini ibu hamil/nifas penderita anemia dengan pemeriksaan $\mathrm{Hb}$, dan pemberian tablet multivitamin zat besi. Berdasarkan hal-hal di atas, maka penulis melakukan penelitian yang berjudul "Faktor-faktor yang Berhubungan dengan Kejadian Anemia Pada Ibu Hamil di BPM Kusmawati Tahun 2018.”

\section{METODE}

Penelitian ini merupakan jenis penelitian observasional analitik. Berdasarkan waktu pelaksanaannya metode yang digunakan dalam penelitian ini adalah cross sectional study, dimana pengukuran variabel dependent dan variabel independent dilakukan secara bersamaan. Populasi yang digunakan dalam penelitian ini adalah teknik total sampling yaitu seluruh ibu hamil TM III di BPS Kusmawati, dilakukan selama 3 bulan sebanyak 45 responden.

Peneliti mengajukan permohonan pengambilan data dari LPPM Universitas Nahdlatul Ulama Surabaya kepada pemilik
Bidan praktik Mandiri, setelah mendapatkan ijin pengambilan data kemudian melakukan pendekatan dengan ibu dan menjelaskan tentang metode penelitian serta melakukan inform consent. Pengumpulan data dilakukan di BPM Kusmawati dari bulan September sampai November tahun 2019 dengan menggunakan data primer yaitu wawancara menggunakan kuesioner dengan pertanyaan berifat terbuka dan tertutup dengan jumlah soal sebanyak 13 soal dan data sekunder berupa buku register PWS KIA. Data yang telah dikumpulkan kemudian diolah secara manual dengan menggunakan program SPSS. Hasil pengolahan data disajikan dalam bentuk tabel dan narasi. Analisa data yang digunakan adalah univariat, bivariate dengan uji statistik menggunakan Chi-Square.

\section{HASIL PENELITIAN}

Hubungan Umur Ibu dengan Kejadian Anemia

Tabel 1 Hubungan antara umur Ibu dengan Kejadian Anemia pada ibu hamil TM III di BPM Kusmawati Surabaya, Tahun 2018

\begin{tabular}{lccccccc}
\hline Umur Ibu & \multicolumn{4}{c}{ Kejadian Anemia } & Total & P \\
\cline { 2 - 5 } & \multicolumn{2}{c}{$\begin{array}{c}\text { Anemi } \\
\text { a }\end{array}$} & \multicolumn{2}{c}{ Tidak } & & & \\
& Anemia & & & \\
& $\mathrm{N}$ & $\%$ & $\mathrm{n}$ & $\%$ & $\mathrm{~N}$ & $\%$ & \\
\hline 20-35 tahun & 1 & 47 & 2 & 53 & 3 & 100 & 0,35 \\
& 8 & & 0 & & 8 & & 8 \\
\hline < 20 dan & 2 & 29 & 5 & 71 & 7 & 100 & \\
$>35$ tahun & & & & & & & \\
\hline
\end{tabular}


Tabel 4.2.1 menunjukkan bahwa sebagian besar (53\%) ibu berumur 20 - 35 tahun tidak mengalami anemia, sedangkan sebagian besar $(712 \%)$ ibu berumur $<20$ atau > 35 tahun tidak mengalami anemia.

Hasil uji statistik diperoleh nilai $\mathrm{p}=$ $0,358(\mathrm{p}>0,05)$ hal ini menunjukkan tidak terdapat hubungan antara umur dengan kejadian anemia pada ibu hamil

Hubungan Status Gizi dengan Kejadian Anemia

Tabel 2 Hubungan antara status Gizi dengan Kejadian Anemia pada ibu hamil TM III di BPM Kusmawati Surabaya, Tahun 2018

\begin{tabular}{lccccccc}
\hline Status & \multicolumn{4}{c}{ Kejadian Anemia } & Total & \multirow{2}{*}{ P } \\
\cline { 2 - 5 } & Anemia & \multicolumn{2}{c}{ Tidak } & & \\
& \multicolumn{5}{c}{ Anemia } \\
& $\mathrm{N}$ & $\%$ & $\mathrm{n}$ & $\%$ & $\mathrm{~N}$ & $\%$ & \\
\hline Baik & 0 & 0 & 24 & 100 & 24 & 100 & 0,000 \\
\hline Kurang & 20 & 95,2 & 1 & 4,8 & 21 & 100 & \\
& & & & & & &
\end{tabular}

Tabel 4.2.2 menunjukkan bahwa seluruh (100\%) responden yang memiliki status gizi baik tidak mengalami anemia, sedangkan hampir seluruh $(95,2 \%)$ responden yang memiliki status gizi kurang mengalami anamia.

Hasil uji statistik diperoleh nilai $\mathrm{p}=$ $0,000 \quad(\mathrm{p}<0,05)$ hal ini menunjukkan adanya hubungan antara status gizi ibu hamil dengan tingkat kejadian anemia.

Hubungan Jumlah Paritas dengan Kejadian Anemia
Tabel 3 Hubungan antara jumlah paritas dengan Kejadian Anemia pada ibu hamil TM III di BPM Kusmawati Surabaya, Tahun 2018

\begin{tabular}{|c|c|c|c|c|c|c|c|}
\hline \multirow{3}{*}{ Paritas } & \multicolumn{4}{|c|}{ Kejadian Anemia } & \multicolumn{2}{|c|}{ Total } & \multirow[t]{2}{*}{$\mathrm{P}$} \\
\hline & \multicolumn{2}{|c|}{ Anemia } & \multicolumn{2}{|c|}{$\begin{array}{c}\text { Tidak } \\
\text { Anemia }\end{array}$} & & & \\
\hline & $\mathrm{N}$ & $\%$ & $\mathrm{~N}$ & $\%$ & $\mathrm{~N}$ & $\%$ & \\
\hline $\begin{array}{l}\text { Resiko Tinggi } \\
\text { (melahirkan >4 } \\
\text { kali) }\end{array}$ & 2 & 25 & 6 & 75 & 8 & 100 & 0,222 \\
\hline $\begin{array}{l}\text { Resiko Rendah } \\
\text { (melahirkan <4 } \\
\text { kali) }\end{array}$ & 18 & 48,6 & 19 & 51,4 & 37 & 100 & \\
\hline
\end{tabular}

Tabel 4.9 menunjukkan bahwa sebagian besar $(75 \%)$ responden yang mempunyai resiko tinggi (melahirkan $>4$ kali) tidak mengalami anemia, sedangkan sebagian besar $(51,4 \%)$ responden yang mempunyai resiko rendah (melahirkan $<4$ kali) tidak mengalami anemia.

Hasil uji statistik diperoleh nilai $\mathrm{p}=$ $0,222(p>0,05)$ hal ini menunjukkan adanya hubungan antara paritas ibu hamil dengan kejadian anemia.

Hubungan Frekuensi antenatal Care (ANC) dengan Kejadian Anemia

Tabel 4 Hubungan antara Frekuensi antenatal Care (ANC) dengan Kejadian Anemia pada ibu hamil TM III di BPM Kusmawati Surabaya, Tahun 2018

\begin{tabular}{|c|c|c|c|c|c|c|c|}
\hline \multirow{3}{*}{$\begin{array}{c}\text { Frekuensi } \\
\text { ANC }\end{array}$} & \multicolumn{4}{|c|}{ Kejadian Anemia } & \multirow{2}{*}{\multicolumn{2}{|c|}{ Total }} & \multirow[t]{3}{*}{$\mathrm{P}$} \\
\hline & \multicolumn{2}{|c|}{ Anemia } & \multicolumn{2}{|c|}{$\begin{array}{c}\text { Tidak } \\
\text { Anemia }\end{array}$} & & & \\
\hline & $\mathrm{n}$ & $\%$ & $\mathrm{~N}$ & $\%$ & $\mathrm{~N}$ & $\%$ & \\
\hline $\begin{array}{l}\text { Tidak } \\
\text { Rutin (<4 } \\
\text { kali) }\end{array}$ & 11 & 92 & 1 & 8 & 12 & 100 & 0,000 \\
\hline $\begin{array}{l}\text { Rutin }(\geq \\
4 \text { kali) }\end{array}$ & 9 & 27 & 24 & 73 & 33 & 100 & \\
\hline
\end{tabular}


Tabel 4.2.4 menunjukkan bahwa hampir seluruh (92\%) responden yang melakukan pemeriksaan kehamilan tidak rutin ( $<4$ kali) mengalami anemia, sedangkan sebagian besar $(73 \%)$ responden yang melakukan ANC secara rutin (4 kali) atau lebih tidak mengalami anemia.

Hasil uji statistik diperoleh nilai $\mathrm{p}=$ $0,000 \quad(\mathrm{p}<0,05)$ hal ini menunjukkan adanya hubungan antara frekuensi ANC dengan kejadian anemia pada ibu hamil

Hubungan Tingkat Pengetahuan dengan kejadian Anemia

Tabel 5 Hubungan antara tingkat pengetahuan dengan kejadian anemia pada ibu hamil TM III di BPM Kusmawati Surabaya, Tahun 2018

\begin{tabular}{|c|c|c|c|c|c|c|c|}
\hline \multirow{3}{*}{$\begin{array}{c}\text { Tingkat } \\
\text { Pengetahuan }\end{array}$} & \multicolumn{4}{|c|}{ Kejadian Anemia } & \multirow{2}{*}{\multicolumn{2}{|c|}{ Total }} & \multirow[t]{3}{*}{$P$} \\
\hline & \multicolumn{2}{|c|}{ Anemia } & \multicolumn{2}{|c|}{$\begin{array}{c}\text { Tidak } \\
\text { Anemia }\end{array}$} & & & \\
\hline & $\mathrm{N}$ & $\%$ & $\mathrm{~N}$ & $\%$ & $\mathrm{~N}$ & $\%$ & \\
\hline Kurang & 10 & 66,7 & 5 & 33,3 & 15 & 100 & 0,034 \\
\hline Cukup & 10 & 33,3 & 20 & 66,7 & 30 & 100 & \\
\hline
\end{tabular}

Tabel 4.2.5 menunjukkan bahwa sebagian besar $(66,7 \%)$ responden yang memiliki tingkat pengetahuan kurang mengalami anemia, sedangkan sebagian besar $(66,7 \%)$ responden yang memiliki tingkat pengetahuan cukup tidak mengalami anemia.

Hasil uji statistik didapatkan nilai $\mathrm{p}=$ $0,034 \quad(\mathrm{p}<0,05)$ hal ini menunjukkan adanya hubungan antara paritas dengan kejadian anemia pada ibu hamil
Hubungan Kepatuhan Konsumsi Tablet Fe dengan Kejadian Anemia

Tabel 6 Hubungan antara kepatuhan konsumsi tablet Fe dengan Kejadian Anemia pada ibu hamil TM III di BPM Kusmawati Surabaya, Tahun 2018

\begin{tabular}{|c|c|c|c|c|c|}
\hline \multirow{3}{*}{$\begin{array}{l}\text { Konsumsi } \\
\text { tablet FE }\end{array}$} & \multicolumn{2}{|c|}{ Kejadian Anemia } & \multirow{2}{*}{\multicolumn{2}{|c|}{ Total }} & \multirow[t]{3}{*}{$\mathrm{P}$} \\
\hline & $\begin{array}{c}\text { Anemi } \\
\mathrm{a}\end{array}$ & $\begin{array}{c}\text { Tidak } \\
\text { Anemi } \\
\text { a }\end{array}$ & & & \\
\hline & $\%$ & $\mathrm{~N} \%$ & $\mathrm{~N}$ & $\%$ & \\
\hline Patuh & $13 \quad 36$ & $23 \quad 64$ & 36 & 100 & 0,024 \\
\hline Tidak patuh & 78 & 22 & 9 & 100 & \\
\hline
\end{tabular}

Tabel 4.2.6 menunjukkan bahwa sebagian besar $(64 \%)$ responden yang patuh mengkonsumsi tablet Fe tidak mengalami anemia, sedangkan hampir seluruh $(78 \%)$ responden yang tidak patuh mengkonsumsi tablet Fe mengalami anemia.

Hasil uji statistik didapatkan nilai $\mathrm{p}=$ $0,024(\mathrm{p}<0,05)$ hal ini menunjukkan adanya hubungan antara kepatuhan konsumsi tablet Fe pada ibu hamil dengan kejadian anemia

\section{PEMBAHASAN}

Hubungan antara umur ibu dengan kejadian anemia pada ibu hamil TM III

Berdasarkan tabel 4.2.1 menunjukkan hasil sebagian besar (53\%) berumur $20-35$ th tidak mengalami anemia, sedangkan sebagian besar $(71 \%)$ berumur $<20$ atau $>35$ th tidak mengalami anemia. Hasil uji statistik diperoleh nilai $p=0,358(p>0,05)$ hal ini menunjukkan tidak terdapat hubungan 
antara umur ibu hamil dengan kejadian anemia.

Defisiensi zat besi timbul pada saat kebutuhan akan zat besi meningkat, misalnya pada wanita usia reproduktif. Ibu hamil pada usia terlalu muda ( $<20$ tahun) tidak atau belum siap untuk memperhatikan lingkungan yang diperlukan untuk pertumbuhan janin. Disamping itu akan terjadi kompetisi makanan antar janin dan ibunya sendiri yang masih dalam pertumbuhan dan adanya pertumbuhan hormonal yang terjadi selama kehamilan. Sedangkan ibu hamil diatas 30 tahun lebih cenderung mengalami anemia, hal ini disebabkan karena pengaruh turunnya cadangan zat bei dalam tubuh akibat masa fertilisasi.

Hal tersebut sesuai dengan pendapat Husaini (2014) yang menyatakan bahwa anemia pada ibu hamil dapat terjadi pada semua tingkat umur, pada tingkat umur yang berbeda terdapat variasi kebutuhan zat besi setiap hari, artinya umur ibu hamil yang terlalu muda atau terlalu tua tidak akan berpengaruh terhadap kejadian anemia pada ibu hamil.

Hubungan antara status gizi dengan kejadian anemia pada ibu hamil TM III

Berdasarkan tabel 4.2.2 menunjukkan bahwa seluruh (100\%) responden yang memiliki status gizi baik tidak mengalami anemia, sedangkan hampir seluruh $(95,2 \%)$ responden yang memiliki status gizi kurang mengalami anemia. Hasil uji statistik diperoleh nilai $\mathrm{p}=0,000(\mathrm{p}<0,05)$ hal ini menunjukkan adanya hubungan antara status gizi ibu hamil dengan kejadian anemia.

Status gizi adalah salah satu faktor penting saat kehamilan, rendahnya status gizi dapat menyebabkan anemia yang mengakibatkan kualitas fisik yang rendah dan berpengaruh pada efisiensi reproduksi. Hal ini di dukung oleh penelitian Marlapan, dkk (2013), ibu hamil sampai proses melahirkan memerlukan zat besi kurang lebih $40 \mathrm{mg} / \mathrm{hari}$ atau dua kali lipat kebutuhan dari kondisi tidak hamil, anemia gizi besi disebabkan karena gizi yang masuk kurang atau tidak adekuat. Penilaian status gizi dibuat untuk mengidentifikasi nutrien yang berperan dalam kasus anemia. Anemia defisiensi besi dapat disebabkan oleh berbagai macam nutrien penting pada pembentukan hemoglobin.

Hubungan antara jumlah paritas dengan kejadian anemia pada ibu hamil TM III

Berdasarkan tabel 4.2.3 menunjukkan bahwa sebagian besar $(75 \%)$ responden yang melahirkan $>4$ kali tidak mengalami anemia, sedangkan sebagian besar $(51,4$ $\%)$ responden yang melahirkan $<4$ kali tidak mengalami anemia. Hasil uji statistik diperoleh nilai $\mathrm{p}=0,222$ hal ini menunjukkan bahwa $p>0,05$ yang berarti tidak terdapat hubungan antara paritas dengan 
kejadian anemia pada ibu hamil, artinya melahirkan lebih atau kurang dari 4 kali tidak memberikan pengaruh terhadap kejadian anemia pada ibu hamil.

Anemia dapat tejadi pada ibu dengan paritas tinggi terkait dengan keadaan biologis ibu dan asupan zat besi dan paritas akan lebih beresiko bila terkait dengan jarak kehamilan yang pendek. Jika kehamilan sebelumnya mengalami anemia dimana cadangan besi di dalam tubuh berkurang maka kehamilan akan menguras persediaan besi di dalam tubuh dan akan menimbulkan anemia pada kehamilan berikutnya. Hal ini didukung oleh penelitian Siti Asyirah (2012) menemukan bahwa jumlah paritas tidak berhubungan dengan kejadian anemia pada ibu hamil. Hasil yang sama ditunjukkan juga oleh penelitian yang dilakukan Yuliastuti, dkk (2014) bahwa tidak ada hubungan yang bermakna antara paritas dengan anemia pada ibu hamil.

Hubungan antara frekuensi ANC dengan kejadian anemia pada ibu hamil TM III

Berdasarkan tabel 4.2.4 menunjukkan bahwa hampir seluruh (92\%) responden yang melakukan pemeriksaan kehamilan< 4 kali mengalami anemia, sedangkan sebagian besar $(73 \%)$ responden yang melakukan pemeriksaan kehamilan 4 kali atau lebih tidak mengalami anemia.
Hasil uji statistik didapatkan nilai $\mathrm{p}=$ $0,000 \quad(\mathrm{p}<0,05)$ hal ini menunjukkan adanya hubungan antara frekuensi pemeriksaan kehamilan dengan kejadian anemia. Hal ini menunjukkan bahwa semakin teratur ibu hamil memeriksakan kehamilannya maka semakin kecil pula ibu hamil mengalami anemia.

Semua ibu hamil dianjurkan melakukan pemeriksaan kehamilan paling sedikit 4 kali selama kehamilan, yaitu 1 kali pada trimester I, 1 kali pada trimester II dan 2 kali pada trimester III, hal ini merupakan upaya yang dilakukan untuk mendeteksi lebih dini bahaya atau komplikasi yang bisa terjadi dalam kehamilan seperti anemia defisiensi besi pada ibu hamil.

Hal ini sesuai dengan yang dikemukakan oleh Rukiyah (2011) bahwa pentingnya pentingnya pemeriksaan kehamilan melalui ANC (Antenatal Care) karena pada umumnya kehamilan berjalan normal tetapi dengan bertambahnya usia kehamilan cenderung berkembang menjadi komplikasi yang beresiko.

Hubungan antara tingkat pengetahuan dengan kejadian anemia pada ibu hamil TM III

Berdasarkan tabel 4.2.5 menunjukkan bahwa sebagian besar $(66,7 \%)$ responden yang memiliki pengetahuan kurang mengalami anemia, sedangkan sebagian besar $(66,7 \%)$ responden yang memiliki penge- 
tahuan cukup tidak mengalami anemia. Hasil uji statistik didapatkan nilai $\mathrm{p}=$ $0,034(p<0,05)$ hal ini menunjukkan adanya hubungan antara paritas dengan kejadian anemia pada ibu hamil. Hal ini menunjukkan bahwa semakin baik pengetahuan ibu hamil tentang anemia dan tablet Fe semakin kecil kemungkinan mengalami anemia dalam kehamilannya.

Pengetahuan ibu hamil yang kurang tentang anemia serta tablet Fe akan mempengaruhi kurangnya konsumsi makanan yang mengadung zat besi selain itu karena efek samping yang ditimbulkan dari tablet Fe ibu cenderung tidak mau dan tidak tepat dalam mengkonsumsi tablet $\mathrm{Fe}$ sehingga ibu hamil mengalami anemia. Semakin banyak pengetahuan yang dimiliki ibu maka semakin beragam pula jenis makanan yang dikonsumsi sehingga dapat memenuhi kecukupan gizi.

Menurut Notoatmojo (2012) faktorfaktor yang dapat mempengaruhi kurangnya pengetahuan ibu hamil tentang anemia dalam kehamilan antara lain kurangnya informasi dari tenaga kesehatan kepada ibu hamil, kurang jelasnya informasi yang disampaikan dan kurangnya kemampuan ibu hamil untuk memahami informasi yang diberikan.

Hubungan antara kepatuhan konsumsi tablet Fe dengan kejadian anemia pada ibu hamil TM III
Tabel 4.2.6 menunjukkan hasil sebagian besar (64\%) responden yang mengkonsumsi tablet $\mathrm{Fe}$ sesuai anjuran tidak mengalami anemia, sedangkan hampir seluruh (78\%) responden yang meng konsumsi tablet $\mathrm{Fe}$ tidak sesuai anjuran mengalami anemia.

Hasil uji statistik didapatkan nilai $\mathrm{p}=$ $0,024(\mathrm{p}<0,05)$ artinya adanya hubungan antara kepatuhan konsumsi tablet Fe pada ibu hamil dengan kejadian anemia. Sehingga jika ibu hami patuh dalam mengkonsumsi tablet $\mathrm{Fe}$ angka kejadian anemia pun akan semakin kecil.

Kepatuhan dalam mengkonsumsi tablet $\mathrm{Fe}$ diukur dari ketepatan jumlah tablet $\mathrm{Fe}$ yang dikonsumsi, ketepatan cara mengkonsumsi dan frekuensi konsumsi per hari sehingga apabila ibu hamil mengkonsumsi tablet $\mathrm{Fe} 1 \mathrm{x}$ sehari secara berturut-turut setiap hari selama kehamilan dengan diminum bersama air putih atau vitamin $\mathrm{C}$ maka kejadian anemia pada ibu hamil dapat dicegah.

Hal ini sesuai dengan teori Hidayah (2012) bahwa suplemen rutin per oral adalah cara terbaik untuk mecegah anemia defisiensi besi pada kehamilan. Ketidakpatuhan terjadi karena keraguan terhadap pemberian suplemen zat besi, efek samping serta ketidaksadaran ibu hamil bahwa mereka membutuhkan zat besi akibatnya salah satu program pemerintah dalam hal pengawasan dan pencegahan 
anemia tidak berhasil, karena salah satu faktornya adalah ketidakpatuhan sehingga hal ini memicu angka kejadian anemia pada kehamilan yang masih relatif tinggi.

\section{SIMPULAN}

1. Tidak terdapat hubungan umur Ibu dengan kejadian anemia pada ibu hamil di BPM Kusmawati.

2. Terdapat hubungan status gizi dengan kejadian anemia pada ibu hamil di BPM Kusmawati.

3. Tidak terdapat hubungan paritas dengan kejadian anemia pada ibu hamil di BPM Kusmawati.

4. Terdapat hubunganFrekuensi Antenatal Care dengan kejadian anemia pada ibu hamil di BPM Kusmawati.

5. Terdapat hubungan tingkat pengetahuan dengan kejadian anemia pada ibu hamil di BPM Kusmawati.

6. Terdapat hubungan kepatuhan mengkonsumsi tablet $\mathrm{Fe}$ dengan kejadian anemia pada ibu hamil di BPM Kusmawati

\section{DAFTAR PUSTAKA}

Amirudin R, Syam m, Rusnah. 2007. Studi kasus kontrol anemia ibu hamil. Jurnal Medika Unhas: Jurnal Medika

Asyirah, S. 2012. Faktor-Faktor Yang Berhubungan Dengan Anemia Pada Ibu Hamil Di Wilayah Kerja Puskesmas Bajeng Kecamatan Bajeng Kabupaten Gowa. Depok: FKM UI
Boyle, Maureen. 2008. Kegawatdaruratan dalam persalinan. Jakarta: Kedokteran EGC

Feryanto, achmad. 2011. Asuhan Kebidanan Patologis. Jakarta: Salemba medika

Hidayah, W dan Anasari, T. 2012. Hubungan Kepatuhan Ibu Hamil Mengkonsumsi Tablet $\mathrm{Fe}$ dengan Kejadian Anemia di Desa Pageraji Kecamatan Cilongok Kabupaten Banyumas. Jurnal Ilmiah Kebidanan. Vol.3 No.2.

Herlina N, Djamilan F. 2006. Faktor Resiko Kejadian Anemia Pada Ibu Hamil Di Wilayah Kerja Puskesmas Bogor. Jakarta: Jurnal Ilmiah Kebidanan. Vol.4 No.2

Kemenkes RI. 2013. Profil Kesehatan Indonesia. Jakarta: Dirjen Pembinaan Kesehatan Masyarakat. Direktorat Bina Gizi Masyarat.

Marlapan, S., Wantouw, B. dan Sambeka, J. 2013. Hubungan Status Gizi dengan Kejadian Anemia pada Ibu Hamil di Wilaah Kerja Puskesmas Tuminting Kec. Tuminting Kota Manado. E journal Keperawatan (e-Kp). Volume 1 Nomor 1.

Manuaba IBG. 2012. Buku Ajar Patologi Obstetri - untuk mahasiswa Kebidanan. Jakarta: EGC

Notoatmodjo, Soekidjo. 2012. Metedologi penelitian Kesehatan. Jakarta: Rineka Cipta.

Proverawati, atikah. 2011. Anemia Dan Anemia Kehamilan. Yogyakarta: Nuha Medika.

Prawirohardjo, Sarwono. 2009. Ilmu Kebidanan. Jakarta:BP-SP.

Rukiyah, Ai Yeyeh dkk. 2009. Asuhan kebidanan I (Kehamilan). Jakarta: Trans Info $\mathrm{M}$

Siswosuharjo, suwignyo \& Fitria Chakrawati. 2010. Panduan super 
lengkap hamil sehat. Semarang: PENEBARPlus+

Sinsin, Iis. 2008. Masa Kehamilan Dan Persalinan. Jakarta:PT ELEX Media Komputindo.

Sulistiyawati, Ari. 2009. Asuhan Kebidanan Pada Masa Kehamilan. Jakarta: Salemba Medika.

Setiadi. 2013. Konsep dan penulisan riset keperawatan. Yogyakarta: Graha Ilmu.

Saifudin, A Bari, dkk. 2007. Ilmu Kebidanan Sarwono Prawirohradjo. Jakarta: Tridasa Printer.

Tarwoto dan wanidar. 2007. Anemia pada ibu hamil, konsep dan penatalaksanaanya. Jakarta: Trans Info Media.
Wiknjosastro. 2010. Ilmu Kebidanan Edisi 3. Jakarta: Yayasan bina pustaka sarwono Prawiroharjdo.

Wibisono, hermawan dan dewi ayu bulan febry kurnia. 2009. Solusi Sehat Seputar Kehamilan. Bandung: Dzikra.

Yukiastuti, E., Tutiana, A., Syahlani, A. 2014. Hubungan Pendidikan Dan Paritas Ibu Dengan Kejadian Anemia Pada Ibu Hamil. Jurnal Dinamika kesehatan Vol.14.

Zebua, A.M. 2011. Faktor-Faktor Yang Berhubungan Dengan Kejadian Anemia Gizi Pada Ibu Hamil Di Wilayah Kerja Puskesmas Tuhemberua Kabupaten Nias Utara. Medan: Fakultas Kesehatan Masyarakat Universitas Sumatera Utara. 